\title{
INSTRUCTIONAL DESAIN PENDIDIKAN KARAKTER \\ DAN IMPLEMENTASINYA PADA PEMBELAJARAN BAHASA ARAB \\ DI MADRASAH TSANAWIYAH AL-MAARIF O1 SINGOSARI MALANG
}

\section{Umi Machmudah - Abdul Wahab Rosyidi ${ }^{1}$}

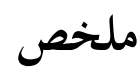

$$
\begin{aligned}
& \text { ان التربية الطبيعية يمكنها ان تندمج فن التعليم في كل من الدراسات. وتطور المواد } \\
& \text { الدراسيات التى تتكون من السلوك و القيم فن كل الدراسات تطورا ملحوظا و متعلقا مع } \\
& \text { السياقات فن الحيات اليومية. فبهذا التطوير لا تنحصر التربية الطبيعية فن مجالات المعرفية } \\
& \text { فقط بل تدخل في الخبرات داخليا وفى خبرات الطلاب فن الحيات اليومية في المجتمع } \\
& \text { تقع مدرسة الثانوية المعارف الواحدة موقعا هاما في ججال التربية الطبيعية لدى لهی } \\
& \text { الطلاب لأن هذه المدرسة تصبح مدرسة مثالية في المنطقة الشمالية التى تحيطها المعاهد } \\
& \text { الاسلامية ويأتوها الطلاب من أى مدن من جاوى الشرقية حتى تكون هذه المدرسة مرجعا } \\
& \text { هاما في عملية التعليم و التعلم وفى مجالات أخرى لاسيما في اندماج التربية الطيعية. }
\end{aligned}
$$

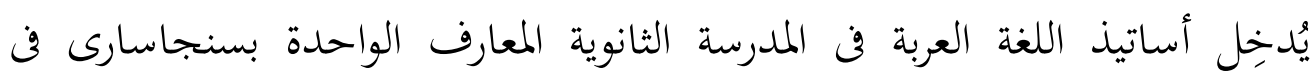

$$
\begin{aligned}
& \text { تصميم دراساقم عناصر التربية الطبيعية في التخطيط الدراسي الذى خططه. ولكن لم تطبق }
\end{aligned}
$$

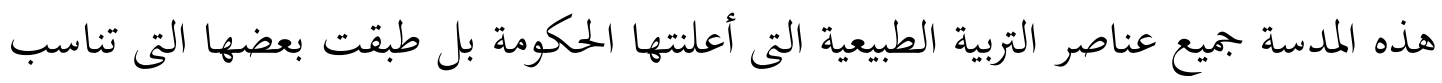

$$
\begin{aligned}
& \text { مع الموضوعات المدروسة. وتلك العناصر الطبيعية التى تدرس فيها فهي: الدينية و الاهتمام } \\
& \text { بالبيئة و النظام النفسي و الرغبة بالمعرفة و الاتصالي او الأخوة و التسامح و الميول الى لى } \\
& \text { القراءة و النشاط في العمل و المسئولية. }
\end{aligned}
$$

Kata Kunci : Instructional Desain, Pendidikan Karakter

\section{A. Latar Belakang}

Pendidikan dari tahun ke tahun tampakya akan tetap menjadi pusat perhatian baik bagi kalangan pemerintah maupun masyarakat. Bahkan PBB menjadikan pendidikan sebagai salah satu aspek penting dalam mencapai Millennium Development Goals (MDGs). Hal ini sangatlah beralasan karena pendidikan merupakan bagian strategis untuk membangun manusia seutuhnya. (Rahardjo, 2010:vii) dan sebagai media yang sangat ampuh dalam membangun kecerdasan sekaligus kepribadian anak manusia agar menjadi lebih baik dan unggul.(Azzet, 2011: 9)

${ }^{1}$ Penulis adalah Dosen Bahasa Arab pada Fakultas Humaniora UIN Maliki Malang. 
Memperhatikan situasi dan kondisi karakter bangsa yang memprihatinkan tersebut, pemerintah mengambil inisiatif untuk memprioritaskan pembangunan karakter bangsa. Pembangunan karakter bangsa seharusnya menjadi arus utama pembangunan nasional. Artinya, setiap upaya pembangunan harus selalu dipikirkan keterkaitan dan dampaknya terhadap pengembangan karaker. Hal itu tecermin dari misi pembangunan nasional yang memposisikan pendidikan karakter sebagai misi pertama dari delapan misi guna mewujudkan visi pembangunan nasional, sebagaimana tercantum dalam Rencana Pembangunan Jangka Panjang Nasional Tahun 2005-2025 (UndangUndang Republik Indonesia Nomor 17 Tahun 2007), yaitu terwujudnya karakter bangsa yang tangguh, kompetitif, berakhlak mulia, dan bermoral berdasarkan Pancasila, yang dicirikan dengan watak dan prilaku manusia dan masyarakat Indonesia yang beragam, beriman dan bertakwa kepada Tuhan Yang Maha Esa, berbudi luhur, bertoleran, bergotongroyong, berjiwa patriotik, berkembang dinamis, dan berorientasi iptek. (Kemendiknas, 2010)

Pendidikan karakter dapat diintegrasikan dalam pembelajaran pada setiap mata pelajaran. Materi pembelajaran yang berkaitan dengan norma atau nilainilai pada setiap mata pelajaran perlu dikembangkan, dieksplisitkan, dikaitkan dengan konteks kehidupan sehari-hari. Dengan demikian, pembelajaran nilainilai karakter tidak hanya pada tataran kognitif, tetapi menyentuh pada internalisasi, dan pengamalan nyata dalam kehidupan peserta didik sehari-hari di masyarakat. (Kemendiknas, 2010).

Madrasah Tsanawiyah Al Maarif 01 Singosari memiliki posisi penting dalam hal penanaman karakter pada siswa, karena MTS Al Maarif 01 merupakan Madrasah favorit di kabupaten Malang bagian utara yang dikelilingi oleh beberapa podok pesantren, disamping itu siswa yang belajar datang dari berbagai kota di Jawa Timur, sehingga lembaga tersebut sering menjadi rujukan dalam hal proses belajar mengajar dan hal-hal lain, termasuk internalisasi pendidikan karakter. Dalam hal pendidikan karakter MTS Al Maarif 01 Singosari jauh sebelumnya telah mencanangkan dalam visinya, sehingga setiap insan yang ada dalam madrasah harus senantiasa menuju ketercapain visi yang ada. Pendidikan karakter tersebut di implementasikan pada kegiatan-kegiatan madrasah dan dalam tataran bidangstudi, termasuk pada bidang studi Bahasa Arab

\section{B. Masalah Penelitian}

Berangkat dari permasalahan di atas, peneliti ingin memfokuskan kajiannya pada hal-hal yang dapat dijadikan sebagai barometer integrasi pendidikan karakter pada pembelajaran bahasa Arab. Hal-hal tersebut adalah sebagai berikut:

1. Bagaimana rumusan pendidikan karakter pada "instructional desaign" pembelajaran bahasa Arab di Madrasah Tsanawiyah Al Maarif 01 Singosari Malang?

2. Bagaimana implementasi pendidikan karakter pada pembelajaran bahasa Arab di Madrasah Tsanawiyah Al Maarif 01 Singosari Malang ? 


\section{Signifikansi Penelitian}

Penelitian dengan judul "Integrasi pendidikan karakter pada pembelajaran bahasa Arab di Madrasah Tsanawiyah Al Maarif 01 Singosari Malang" ini, diharapkan memberikan kontribusi pada:

1. Kementerian Agama dan Kementerian Pendidikan dan Kebudayaan khususnya Kementerian Agama Kabupaten Malang, bahwa hasil penelitian ini diharapkan menjadi acuan atau pedoman pelaksanaan pendidikan karakter pada pembelajaran bahasa Arab di madrasah-madrasah lain.

2. Pihak sekolah dan Guru bahasa Arab dari Madrasah Tsanawiyah Al Maarif 01 Singosari Malang, bahwa hasil penelitian ini diharapkan sebagai refleksi dari aktifitas pembelajaran yang sudah dilaksanakan, mempertahankan nilainilai positif yang sudah ada dan jika didapatkan kekurangan maka akan dijadikan bahan evaluasi .

3. Calon guru/ pengajar bahasa Arab, bahwa hasil penelitian ini dapat dijadikan acuan dalam menerapkan nilai-nilai pendidikan karakter pada pembelajaran bahasa Arab.

\section{Metodologi Penelitian}

\section{Jenis Penelitian.}

Penelitian dengan judul "Integrasi pendidikan karakter pada pembelajaran bahasa Arab di Madrasah Tsanawiyah Al Maarif 01 Singosari Malang" ini adalah termasuk penelitian deskriptif, yakni penelitian yang bermaksud membuat pencandraan (deskripsi) mengenai situasi-situasi atau kejadian-kejadian yang diantara tujuannya adalah mencari informasi faktual yang mendetail yang mencandra gejala yang ada. ( Suryabrata, 2008: 76) atau dengan kata lain menggambarkan lebih teliti ciri-ciri sesuatu. (Sukandarrumidi, 2006: 114)

\section{Pendekatan Penelitian}

Penelitian ini disusun dengan menggunakan pendekatan kualitatif, yakni sebuah prosedur penelitian yang menghasilkan data deskriptif berupa kata-kata tertulis atau lisan dari orang-orang dan perilaku yang diamati (Moleong, 1990:3)

\section{Langkah-langkah Pengumpulan Data}

Langkah-langkah yang ditempuh dalam pengumpulan data pada penelitian ini adalah sebagai berikut: (a) mengumpulkan dokumen "instructional desaign" yang berupa RPP pelajaran bahasa Arab kelas VIII, bab I dan II, (b) melakukan pengamatan (observasi) pada kelas sampel, (c) menganilis sesuai dengan karakteristik data. (Arikunto, 2006: 238)

\section{Instrumen Pengumpul Data}

Dengan melihat fokus penelitian diatas, maka instrument pengumpul datanya adalah (a) dokumen, dan (b) pengamatan (observasi) dengan menggunakan pedoman observasi (Arikunto, 2006: 239)

\section{Sumber data}

Sumber data dari penelitian ini meliputi paper dan person.( Arikunto, 2006: 47). Uraian kedua hal tersebut sebagai berikut: (a) Paper dalam hal ini adalah dokumen RPP (Rencana Pelaksanaan Pembelajaran) sebagai wujud dari "instructional desaign", (b) Person, dalam hal ini adalah aktifitas guru bahasa Arab Madrasah Tsanawiyah Al Maarif 01 Singosari Malang dan 
aktifitas siswa-siswi pebelajar bahasa Arab di kelas VIII. Sampel diambil secara purposive rasional (purposive sampling) (Kasiram, 2010: 180) dengan pertimbangan kelas yang diajar oleh guru bahasa Arab yang paling banyak mengaplikasikan pendidikan karakter dalam proses belajar mengajarnya. Sampel yang diteliti dipandang dapat memberikan data secara maksimal (Arikunto, 2006: 16)

\section{Analisis Data.}

Analisis data dalam penelitian ini meliputi: (a) Data yang terkumpul berupa dokumen tertulis yakni RPP dianalisis dengan "Analisis Isi (content analysis) (Arikunto, 2006: 266). Analisis dilakukan dengan melihat sisi penerapan butir-butir karakter pada tiap-tiap aspek yang ada pada RPP, baik itu pada standar kompetensi (SK), kompetensi dasar (KD), Indikator, Media/ Sumber Belajar, tujuan pembelajaran, metode pembelajaran, skenario pembelajaran, Alat dan Sumber Belajar, dan Penilaian, dianalisis dengan kesesuaiannya dengan berpijak pada tujuan pembelajaran yang telah ditetapkan. Data diklasifikasi sesuai tingkatan kelas, analisis dilakukan agar menemukan spesifikasi dari tiap-tiap tingkatan. Kesesuaian rumusan RPP dilihat dengan barometer rambu-rambu yang ada pada kajian teori tentang desain instruksional. (b) Untuk menemukan proses pembelajaran bahasa Arab yang mengimplementasikan pendidikan karakter secara menyeluruh, digunakan analisa taksonomi (taxonomic analysis). (Arikunto, 2006: 256)

\section{E. Kajian Teori}

\section{Instructional Design}

Instructional Desaign atau desain intruksional adalah keseluruhan proses analisis kebutuhan dan tujuan belajar serta pengembangan tekhnik mengajar dan materi pengajarannya untuk memenuhi kebutuhan tersebut, termasuk di dalamnya adalah pengembangan paket pembelajaran, kegiatan mengajar, uji coba, revisi dan kegiatan mengevaluasi hasil belajar (Briggs, 1979: 20). Desain sistem instruksional ialah pendekatan secara sistematis dalam perencanaan dan pengembangan sarana serta alat untuk mencapai kebutuhan dan tujuan intruksional. Semua konsep sistem ini (tujuan, materi, metode, media, alat, evaluasi) dalam hubungannya satu sama lain dipandang sebagai kesatuan yang teratur sistematis. Komponen-komponen tersebut lebih dahulu diuji coba efektifitasnya sebelum disebarluaskan penggunaannya (Briggs, 1979 : XXI). Pengembangan sistem intruksional adalah suatu proses menentukan dan menciptakan situasi dan kondisi tertentu yang menyebabkan siswa dapat berinteraksi sedemikian rupa sehingga terjadi perubahan di dalam tingkah lakunya (Carrey 1977 : 6)

\section{Pendidikan Karakter}

Karakter dimaknai sebagai cara berpikir dan berperilaku yang khas tiap individu untuk hidup dan bekerjasama, baik dalam lingkup keluarga, masyarakat, bangsa, dan Negara. Individu yang berkarakter baik adalah individu yang dapat membuat keputusan dan siap mempertanggungjawabkan setiap akibat dari keputusannya.

Sebagai identitas atau jati diri suatu bangsa, karakter merupakan nilai dasar perilaku yang menjadi acuan tata nilai interaksi antar-manusia. Secara 
universal berbagai karakter dirumuskan sebagai nilai hidup bersama berdasarkan atas pilar : kedamaian (peace), menghargai (respect), kerjasama (cooperation), kebebasan (freedom), kebahagiaan (happines), kejujuran (honesty), kerendahan hati (humility), kasih sayang (love), tanggungjawab (responsibility), kesederhanaan (simplicity), toleransi (tolerance), dan persatuan (unity). Karakter seseorang juga dipengaruhi oleh faktor hereditas dan faktor lingkungan.

Mengacu pada pengertian dan faktor yang dapat memengaruhi karakter di atas, maka karakter dapat dimaknai sebagai nilai dasar yang membangun pribadi seseorang, terbentuk baik karena pengaruh hereditas maupun pengaruh lingkungan, yang membedakannya dengan orang lain, serta diwujudkan dalam sikap dan perilakunya dalam kehidupan sehari-hari.

Pendidikan karakter adalah upaya sadar dan sungguh-sungguh dari seorang guru untuk mengajarkan nilai-nilai kepada para siswanya (Winton, 2010). Pendidikan karakter menurut Burke (2001) semata-mata merupakan bagian dari pembelajaran yang baik dan merupakan bagian yang fundamental dari pendidikan yang baik. Pendidikan karakter dapat didefinisikan secara luas atau secara sempit. Dalam makna yang luas pendidikan karakte rmencakup hampir seluruh usaha sekolah di luar bidang akademis terutama yang bertujuan untuk membantu siswa tumbuh menjadi seseorang yang memiliki karakter yang baik. Dalam makna yang sempit pendidikan karakter dimaknai sebagai sejenis pelatihan moral yang merefleksikan nilai tertentu.

\section{Prinsip-Prinsip Pendidikan Karakter}

Pendidikan karekter harus didasarkan pada prinsip-prinsip sebagai berikut:

a. Mempromosikan nilai dasar etika sebagai basis karakter

b. Mengenditifikasi karekter secara komprehensif supaya mencakup pemikiran, perasaan, dan perilaku.

c. Menggunakan pendekatan yang tajam, proaktif, dan efektif untuk membangun karakter.

d. Menciptakan komunitas sekolah yang peduli lingkungan.

e. Memberi kesempatan kepada peserta didik untuk menunjukkan perilaku yang baik.

f. Memiliki cakupan kurikulum yang bermakna dan menantang yang menghargai semua peserta didik, membangun karakter mereka, dan membantu mereka untuk sukses.

g. Mengevaluasi tumbuhnya motivasi diri pada peserta didik.

h. Memfungsikan seluruh staf sekolah sebagai komunitas moral yang berbagi tanggungjawab untuk pendidikan karakter dan setia pada nilai dasar yang sama.

i. Adanya pembagian kepemimpinan moral dan dukungan luas dalam membangun inisiatif pendidikan karakter.

j. Memfungsikan keluarga dan anggota masyarakat sebagai mitra dalam usaha membangun karakter.

k. Mengevaluasi karakter sekolah, fungsi staf sekolah sebagai guru-guru karakter, dan manifestasi karakter positif dalam kehidupan peserta didik. 


\section{Pendidikan Karakter secara Terpadu melalui Pembelajaran}

Di dalam pembelajaran dikenal tiga istilah, yaitu pendekatan, metode, dan pembelajaran. pendekatan pembelajaran bersifat lebih umum, berkaitan dengan seperangkat asumsi berkenaan dengan hakikat pembelajaran. Metode pembelajaran merupakan rencana menyulurah tentang penyajian materi ajar secara sistematis dan berdasarkan pendekatan yang ditemukan. Tehnik pemelajaran adalah kegiatan spesifik yang diimplementasikan dalam kelas/lab sesuai dengan pendekatan metode yang dipilih. Dengan demikian dapat ditegaskan bahwa pendekatan bersifat procedural, dan tehnik bersifat operasional (Abdul Majid, 2005). Namun demikian, beberapa ahli dan praktisi sering kali tidak membedakan ketiga istilah tersebut secara tegas. Sering kali mereka menggunakan ketiga istilah tersebut dengan pengertian yang sama.

Setidaknya terdapat dua pertanyaan mendasar yang perlu diperhatikan berkaitan dengan proses pembelajaran, yaitu (1) sejauh mana efektifitas guru dalam melaksanakan pembelajaran, (2) sejauh mana peserta didik dapat belajar dan menguasai materi pelajaran yang diharapkan. Proses pembelajaran dikatakan efektif apabila gurudapat menyampaikan keseluruhan materi pelajaran yang baik dan peserta didik dapat menguasai subtansi tersebut sesuai dengan tujuan pembelajarann.

Dewasa ini dikenal berbagai istilah mengenai pembelajaran, antara lain pembelajaran kontekstual, pembelajaran PAKEM, pembelajaran tuntas, pembelajaran berbasis kompetensi, dan sebagainya. Pembelajaran profesional sesuai dengan tujuan, karasteristik materi pelajaran, dan karesteristik peserta didik, serta dilaksanakan oleh guru profesional dengan dukungan fasilitas yang memadai sehingga dapat mencapai hasil belajar yang optimal. Dalam pelaksanaannya, pembelajaran profesional menggunakan berbagai teknik atau metode dan media serta sumber belajar yang bervariasi sesuai dengan karakteristik materi dan peserta didik.

Karakteristik pembelajaran profesional antara lain efektif, efisien, aktif, kreatif, inovatif, menyenangkan, dan mencerdaskan. Tujuan pembelajaran dapat dicapai oleh peserta didik yang diharapkan. Seluruh kompetensi (kognisi, afeksi, dan psikomotor) dikuasai peserta didik. Guru secara aktif memantau, membimbing, dan mengarahkan kegiatan belajar peserta didik. Pembaharuan dan penyempurnaan pembelajaran (setrategi, materi, media \& dan sumber belajar, dan sebagainya) perlu terus dilakukan agar dicapai hasil belajar yang optimal.

Pendidikan karakter secara terpadu di dalam pembelajaran adalah pengenalan nilai-nilai, fasilitasi diperolehnya kesadaran akan pentingnya nilai-nilai, dan penginternalisasian nilai-nilai ke dalam tingkah laku peserta didik sehari-hari melalui proses pembelajaran, baik yang berlangsung di dalam maupun di luar kelas pada semua mata pelajaran, selain untuk menjadikan peserta didik menguasai kompetensi atau (materi) yang ditargetkan, juga dirancang untuk menjadikan peserta didik mengenal, menyadari, peduli, menginternalisasi nilai-nilai, dan menjadikannya perilaku. 
Dalam struktur kurikulum sekolah, pada dasarnya setiap mata pelajaran memuat materi-,materi yang berkaitan dengan karakter. Secara substantif, setidaknya terdapat dua mata pelajaran yang terkait langsung dengan pengembangan budi pekerti dan akhlak mulia, yaitu Pendidikan Agama dan pendidikan kewarganegaraan $(\mathrm{Pkn})$. Kedua mata pelajaran tersebut merupakan mata pelajaran tersebut mengarah pada internalisasi nilainilai di dalam tingkah laku sehari-hari melalui proses pembelajaran dari tahapan perencanaan, pelaksanaan, dan penilaian.

5. Implementasi Pendidikan Karakter dalam Pembelajaran Bahasa Arab.

Pada tataran implementasi ini yang perlu dicermati adalah bagaimana guru bahasa Arab mempraktekkan segala hal yang tertulis dalam RPP yang telah direncanakan pada aktifitas belajar mengajarnya di kelas, terutama aktifitas dalam mengimplementasikan pendidikan karakter. Implementasi ini terwujud tatkala guru telah mengintegrasikan nilai-nilai pendidikan karakter pada instructional design dengan rumusan yang jelas.

Ada beberapa prinsip yang harus diperhatikan guru dalam mengintegrasikan pendidikan karakter pada proses pembelajaran: (a) Berkelanjutan, (b) Melalui semua mata pelajaran, pengembangan diri, dan budaya sekolah, (c) Nilai tidak diajarkan tapi dikembangkan, (d) Proses pendidikan dilakukan peserta didik secara aktif dan menyenangkan.

Adapun nilai-nilai yang dikembangkan dalam pendidikan karakter adalah: (a) Religuis, (b) Jujur, (c) Toleransi, (d) Disiplin, (e) Kerja keras, (f) Kreatif, (g) Mandiri, (h) Demokratis, (i) Rasa ingin tahu, (j) Semangat kebangsaan, (k) Cinta tanah air, (l) Menghargai prestasi, (m) Bersahabat/komunikatif, (n) Cinta damai, (o) Gemar Membaca, (p)Peduli lingkungan, (q) Peduli social, (r) Tanggungjawab.

F. Pembahasan

1. Desain Intruksional Pendidikan Karakter pada Pelajaran Bahasa Arab di MTs Al Maarif 01 Singosari

Contoh; Rencana Pelaksanaan Pembelajaran ( RPP) Bahasa Arab BerKarakter Dengan Tema " An Nasyaathot Fil Madrasah" Al Kalam

Jenjang

Mata Pelajaran

: MTs Al.Maarif 01 Singosari

Kelas/Semester

: Bahasa Arab

Pokok Bahasan

: VIII/I

Sub pokok bahasan

النشاطات في المدرسة :

Waktu

: Muharah Al Kalam

Pendekatan

: 2 x 45 menit

Metode

: Contekstual Teaching and Learning

: Direct metode

\section{A. Standar Kompetensi}

Memahami pikiran, perasaan dan pengalaman secara kisan dalam bentuk paparan atau dialog sederhana tentang lingkungan sekolah dan kegiatannya. 


\section{B. Kompetensi Dasar}

1. Melakukan dialog sederhana tentang النشاطات في المدرسة

2. Menyampaikan informasi secara lisan dalam kalimat sederhana النشاطات في المدرسة tentang

\section{Indikator}

1. Siswa dapat melakukan percakapan sederhana dengan baik dan benar.

2. Siswa dapat menjelaskan percakapan yang telah mereka pelajari dengan baik dan benar seputar النشاطات في المدرسة dengan menggunakan Bahasa Arab dengan baik dan benar.

3. Siswa dapat mengulang materi yang telah mereka dengar dan memaparkannya di depan kelas dengan baik dan benar seputar النشاطات في المدرسة

4. Siswa dapat memadukan kosakata yang baru dipelajari dengan beberapa kosakata yang telah dikuasainya dan mengembangkannya dalam bentuk khiwar atau mengarang lisan didepan kelas.

5. Siswa dapat membuat berbagi kalimat bahasa Arab secara lisan seputar المدرسة النشاطات في dengan baik dan benar.

6. Siswa dapat menggabungkan berbagai macam kalimat secara lisan kedalam Bahasa Arab tentang النشاطات في المدرسة dengan baik dan benar.

\section{Materi Pembelajaran}

Contoh khiwar :

$$
\text { - +ادرس في الأسبوع ستتة أيا م الأسبو؟؟ }
$$

E. Nilai karakter yang akan ditanamkan meliputi:

Relegius, Peduli Lingkungan, Disiplin Diri, Rasa Ingin Tahu, Komunikatif/Bersahabat, Toleransi, Gemar Membaca, Kerja Keras, Tanggung Jawab.

F. Kegiatan pembelajaran

1. Guru menyampaikan mufrodat

2. Guru memberikan contoh khiwar

3. Siswa menirukan dan melakukan khiwar berpasangan dengan teman

G. Langkah-langkah Kegiatan

\begin{tabular}{|l|l|l|}
\hline No & Kegiatan Guru & Siswa \\
\hline 1. & Apersepsi (Menfokuskan Masalah) & Apersepsi \\
\hline & $\begin{array}{l}\text { 1. Salam dan tegur sapa } \\
\text { 2. Absensi siswa }\end{array}$ & $\begin{array}{l}\text { 1. Siswa menjawab } \\
\text { salam guru }\end{array}$ \\
$\begin{array}{ll}\text { 3. Membuat kesepakatan kelas } \\
\text { 4. Memperkenalkan media yang telah dibawa } \\
\text { 5. Memberikan pertanyaan untuk menumbuhkan } \\
\text { semangat siswa lewat media. }\end{array}$ & $\begin{array}{l}\text { Siswa } \\
\text { mendengarkan dan } \\
\text { memperhatikan apa } \\
\end{array}$ & yang diucapkan \\
\hline
\end{tabular}




\begin{tabular}{|c|c|c|}
\hline & $\begin{array}{l}\text { 6. Guru memberi khiwar seputar النشاطات فى المدرسة dan memberikan mufrodat baru pada siswa } \\
\text { danaruara }\end{array}$ & $\begin{array}{l}\text { guru } \\
\text { 3. Siswa merespon apa } \\
\text { yang telah } \\
\text { dilakukan guru }\end{array}$ \\
\hline 2. & $\begin{array}{l}\text { Kegiatan inti } \\
\text { 1. Guru menjelaskan mufrodat tentang khiwar dan } \\
\text { guru menjelaskan kosakata baru. } \\
\text { 2. Guru memberikan contoh kalimat yang sesuai } \\
\text { dengan kosakata. } \\
\text { 3. Guru menjelaskan makna kalimat yang } \\
\text { terkandung. } \\
\text { 4. Guru memberikan kesempatan siswa untuk } \\
\text { membuat contoh kalimat yang terkandung } \\
\text { dalam mufrodat. } \\
\text { 5. Guru memberikan contoh khiwar sederhana } \\
\text { yang sesuai dengan kosakata. } \\
\text { 6. Guru memberikan kesempatan kepada siswa } \\
\text { untuk membuat kelompok yang terdiri dari dua } \\
\text { anak. } \\
\text { 7. Guru memberikan kesempatan kepada siswa } \\
\text { untukm berdiskusi membuat khiwar sesuai } \\
\text { dengan mufrodad, seperti yang telah } \\
\text { dicontohkan. }\end{array}$ & $\begin{array}{l}\text { 1. Siswa berlatih } \\
\text { mengucapkan } \\
\text { kosakata baru, dan } \\
\text { memahami artinya. } \\
\text { 2. Siswa dapat } \\
\text { merespon apa yang } \\
\text { telah disampaikan } \\
\text { oleh guru }\end{array}$ \\
\hline 3. & $\begin{array}{l}\text { Penutup } \\
\text { 1. Guru memberi kesempatan kepada siswa untuk } \\
\text { bertanya tentang materi yang belum dipahami. } \\
\text { 2. Guru memberikan kesempatan siswa selama } 7 \\
\text { menit untuk maju kedepan kelas sesuai dengan } \\
\text { kelompok masing-masing dengan } \\
\text { mengungkapkan khiwar yang telah mereka } \\
\text { diskusikan. } \\
\text { 3. Guru mengavaluasi siswa ditengah-tengah } \\
\text { pelajaran dengan menjawab pertanyaan tentang } \\
\text { tema dan memberikan contoh sesuai dengan } \\
\text { kosakata yang ada. } \\
\text { 4. Guru memberikan motivasi dan semangat } \\
\text { belajar kepada siswa untuk cinta dan selalu } \\
\text { menggunakan Bahasa Arab dalam percakapan } \\
\text { sehari. } \\
\text { 5. Salam }\end{array}$ & $\begin{array}{l}\text { 1. Siswa mengingat } \\
\text { kembali apa yang } \\
\text { telah dijelaskan } \\
\text { 2. Siswa menjawab } \\
\text { salam }\end{array}$ \\
\hline
\end{tabular}

\section{F. Penilaian}

Partisipasi siswa selama mengikuti PMB berlangsung di kelas dan ulangan harian, dengan melalui pertanyaan lisan ataupun tulis., serta ulangan praktek.

\section{G. Referensi}


1. Dr. D. Hidayat, - Pelajaran Bahasa Arab. PT. Karya Toha Putra Semarang 2009

2. Robi'ah Ummi Kulsum dan Muhdil Anam. Penuntun Belajar Bahasa Arab, untuk MTs.penerbit Arya Duta, Depok.

3. Abdurohman Ibn Ibrahim Al Fauzan, dkk. Al Arabiyah Baina yadaika. Jilid I, massahn Waqf Al Islami.

\section{H. Analisis Hasil Belajar dan program tindak lanjut.}

1. Penugasan.

2. Tindak Lanjut

Dari paparan desain intruksional bahasa Arab dengan tema " An Nasyaathot Fil Madrasah" tersebut di atas, dapat dikatakan bahwa dalam desain tersebut guru bahasa Arab telah memasukkan unsur penanaman karakter dalam proses belajar mengajar yang dirancangnya. Namun dari unsur pendidikan karakter yang telah dicanangkan oleh pemerintah tidak semuanya bisa ditanamkan pada proses belajar mengajar, namun hanya unsur-unsur karakter yang sesuai dengan tema yang diajarkan, hal ini disebabkan karena tema-tema yang diajarkan sangat terbatas. Unsur karakter tersebut sangat tampak pada masing-masing keterampilan bahasa; Istima' Kalam, Qiro'ah, dan Kitabah, disamping itu sosok guru juga menjadi teladan karakter bagi siswa. Adapun unsur karakter yang ditanamkan meliputi; Relegius, Peduli Lingkungan, Disiplin Diri, Rasa Ingin Tahu, Komunikatif/Bersahabat, Toleransi, Gemar Membaca, Kerja Keras, Tanggung Jawab.

\section{Implementasi Pendidikan Karakter Pada Proses Belajar Mengajar Bahasa Arab Di MTs Al Maarif 01 Singosari}

Dari hasil observasi dalam proses belajar mengajar bahasa Arab di kelas VIII dan intervew dengan guru bahasa Arab dan wakil kepala bidang kurikulum, maka dapat dipaparkan data dalam bentuk tabel sebagai berikut:

Dari data tersebut di atas dapat dijelaskan bagaimana proses

penanaman nilai karakter dalam prosese belajar mengajar;

\begin{tabular}{|c|c|c|c|}
\hline No & Aktivitas Mengajar & Nilai Karakter yang di tanamkan & Keterangan \\
\hline \multicolumn{4}{|c|}{ الساعة } \\
\hline 1 & $\begin{array}{l}\text { Pembukaan; } \\
\text { Mengucapkan salam, } \\
\text { merapikan bangku, dan } \\
\text { berdo'a bersama }\end{array}$ & $\begin{array}{l}\text { Relegius, peduli lingkungan, } \\
\text { membiasakan siswa untuk selalu } \\
\text { mengucapkan salam ketika bertemu, } \\
\text { dan mengawali pekerjaan (belajar) } \\
\text { dengan berdo'a kepada Allah SWT, } \\
\text { dan merapikan lingkungan mereka } \\
\text { tinggal (belajar) }\end{array}$ & $\begin{array}{l}\text { Tema "As } \\
\text { Saa'ah" }\end{array}$ \\
\hline 2 & $\begin{array}{l}\text { Mengucapkan } \\
\text { kosakata baru }\end{array}$ & $\begin{array}{l}\text { Disiplin diri, membiasakan siswa } \\
\text { untuk mendengarkan dan mencermati } \\
\text { kosakata yang diucapkan guru atau }\end{array}$ & Al Istma’ \\
\hline
\end{tabular}




\begin{tabular}{|c|c|c|c|}
\hline & & $\begin{array}{l}\text { orang lain (menjadi pendengar yang } \\
\text { baik, mendengarkan dan merespon } \\
\text { kembali apa yang didengar). Rasa } \\
\text { Ingin tahu, dengan mendengarka } \\
\text { kosakata baru yang belum pernah } \\
\text { diketahuinya akan menimbulkan rasa } \\
\text { ingin tahu arti dari kosakata yang } \\
\text { diucapkan }\end{array}$ & \\
\hline 3 & $\begin{array}{l}\text { Memberikan contoh } \\
\text { percakapan sederhana, } \\
\text { dan praktek } \\
\text { percakapan }\end{array}$ & $\begin{array}{l}\text { Komunikatif/bersahabat, Toleransi, } \\
\text { dalam percakapan sederhana siswa } \\
\text { berlatih dan membiasakan diri untuk } \\
\text { berkomunikasi dengan sesama teman } \\
\text { di kelas dengan baik sehingga terjadi } \\
\text { persahabatan dengan bertanya, jam } \\
\text { berapa bangun, jam berapa makan } \\
\text { pagi dan kegiatan-kegiatan lain, } \\
\text { sehingga akan dimengerti kegiatan } \\
\text { masing-masing temannya yang } \\
\text { berbeda-beda. }\end{array}$ & Al Kalam \\
\hline 4 & $\begin{array}{l}\text { Menjelaskan tata } \\
\text { bahasa yang } \\
\text { terkandung dalam } \\
\text { tema }\end{array}$ & $\begin{array}{l}\text { Rasa Ingin Tahu, menanamkan rasa } \\
\text { ingin tahu akan bentuk-bentuk kalimat } \\
\text { yang terdapat dalam bahasa Arab atau } \\
\text { penggunaan kata tanya. }\end{array}$ & \\
\hline 5 & $\begin{array}{lr}\text { Memberikan } & \text { contoh } \\
\text { bahan bacaan dan } & \text { is } \\
\text { menjelaskan } & \text { isindungannya, } \\
\text { kandan } \\
\text { praktek membaca }\end{array}$ & $\begin{array}{l}\text { Gemar Membaca, disiplin, kerja } \\
\text { keras, membiasakan siswa untuk } \\
\text { membaca dan memahami isi } \\
\text { kandungan apa yang dibaca untuk } \\
\text { menambah pengetahuannya, dengan } \\
\text { cara memanfaatkan waktu yang } \\
\text { dimiliki oleh siswa atau dengan } \\
\text { membuat jadwal kegiatan sehari-hari. } \\
\text { Karena isi bacaan dalam tema } \\
\text { tersebuti tentang mengatur waktu dan } \\
\text { mengisinya dengan berbagai kegiatan }\end{array}$ & Al Qiro'ah \\
\hline 6 & $\begin{array}{l}\text { Memberikan contoh } \\
\text { cara mengerjakan soal- } \\
\text { soal dalam bentuk tulis } \\
\text { tentang tema yang } \\
\text { dipelajari }\end{array}$ & $\begin{array}{l}\text { Tanggung Jawab, Demokratis, } \\
\text { membiasakan siswa untuk } \\
\text { menyelesaikan soal-soal latihan } \\
\text { secara mandiri atau kelompok dan } \\
\text { mempresentasikannya di papan tulis } \\
\text { kemudian dikoreksi bersama-sama, } \\
\text { dan siswa berlatih dengan jawaban } \\
\text { yang berbeda (redaksi berbeda) tapi } \\
\text { sama-sama benarnya. }\end{array}$ & Al Kitabah \\
\hline
\end{tabular}




\begin{tabular}{|c|c|c|c|}
\hline 7 & $\begin{array}{l}\text { Penutup; kesimpulan, } \\
\text { memberikan motivasi, } \\
\text { berdo'a. }\end{array}$ & $\begin{array}{l}\text { Kerja Keras, disiplin, tanggung jawab, } \\
\text { relegius. Dimana siswa diberikan } \\
\text { motivasi untuk selalu meningkatkan } \\
\text { belajar dengan cara mendisiplinkan } \\
\text { diri dan mengatur waktu, serta } \\
\text { menggunakannya dengan sebaik- } \\
\text { baiknya. }\end{array}$ & \\
\hline \multicolumn{4}{|c|}{ النشاطات في المدرسة } \\
\hline 1 & $\begin{array}{l}\text { Mengucapkan salam, } \\
\text { merapikan bangku, dan } \\
\text { berdo'a bersama }\end{array}$ & $\begin{array}{l}\text { Relegius, peduli lingkungan, } \\
\text { membiasakan siswa untuk selalu } \\
\text { mengucapkan salam ketika bertemu, } \\
\text { dan mengawali pekerjaan (belajar) } \\
\text { dengan berdo'a kepada Allah SWT, } \\
\text { dan merapikan lingkungan mereka } \\
\text { tinggal (belajar) }\end{array}$ & $\begin{array}{l}\text { Tema "An } \\
\text { Nasyathot } \\
\text { Fil } \\
\text { Madrasah" }\end{array}$ \\
\hline 2 & $\begin{array}{l}\text { Mengucapkan } \\
\text { kosakata baru }\end{array}$ & $\begin{array}{l}\text { Disiplin diri, membiasakan siswa } \\
\text { untuk mendengarkan dan mencermati } \\
\text { kosakata yang diucapkan guru atau } \\
\text { orang lain (menjadi pendengar yang } \\
\text { baik, mendengarkan dan merespon } \\
\text { kembali apa yang didengar). Rasa } \\
\text { Ingin tahu, dengan mendengarka } \\
\text { kosakata baru yang belum pernah } \\
\text { diketahuinya akan menimbulkan rasa } \\
\text { ingin tahu arti apa yang diucapkan }\end{array}$ & Al Istma' \\
\hline 3 & $\begin{array}{l}\text { Memberikan contoh } \\
\text { percakapan sederhana, } \\
\text { dan praktek } \\
\text { percakapan }\end{array}$ & $\begin{array}{l}\text { Komunikatif/bersahabat, Toleransi, } \\
\text { dalam percakapan sederhana siswa } \\
\text { berlatih dan membiasakan diri untuk } \\
\text { berkomunikasi dengan sesama teman } \\
\text { di kelas dengan baik sehingga terjadi } \\
\text { persahabatan dengan bertanya, jam } \\
\text { berapa bangun, jam berapa makan } \\
\text { pagi dan kegiatan-kegiatan lain, } \\
\text { sehingga akan dimengerti kegiatan } \\
\text { masing-masing temannya yang } \\
\text { berbeda-beda. }\end{array}$ & Al Kalam \\
\hline 4 & $\begin{array}{l}\text { Menjelaskan tata } \\
\text { bahasa yang } \\
\text { terkandung dalam } \\
\text { tema }\end{array}$ & $\begin{array}{l}\text { Rasa Ingin Tahu, menanamkan rasa } \\
\text { ingin tahu akan bentuk-bentuk kalimat } \\
\text { yang terdapat dalam bahasa Arab } \\
\text { dalam hal ini penggunaan kata tanya. }\end{array}$ & \\
\hline 5 & $\begin{array}{lr}\text { Memberikan } & \text { contoh } \\
\text { bahan bacaan dan } \\
\text { menjelaskan }\end{array}$ & $\begin{array}{l}\text { Gemar Membaca, disiplin, } \\
\text { keras, membiasakan siswa untuk } \\
\text { membaca dan memahami }\end{array}$ & Al Qiro'ah \\
\hline
\end{tabular}




\begin{tabular}{|l|l|l|l|}
\hline & $\begin{array}{l}\text { kandungannya, dan } \\
\text { praktek membaca }\end{array}$ & $\begin{array}{l}\text { kandungan apa yang dibaca untuk } \\
\text { menambah pengetahuannya, dengan } \\
\text { cara memanfaatkan waktu yang } \\
\text { dimiliki oleh siswa di sekolah dengan } \\
\text { mengisi beberapa kegiatan baik di } \\
\text { dalam kelas atau di luar kelas. }\end{array}$ \\
\hline 6 & $\begin{array}{l}\text { Memberikan contoh } \\
\text { cara mengerjakan soal- } \\
\text { soal dalam bentuk tulis } \\
\text { tentang tema yang } \\
\text { dipelajari }\end{array}$ & $\begin{array}{l}\text { Tanggung Jawab, Demokratis, } \\
\text { menghargai prestasi, membiasakan } \\
\text { siswa untuk menyelesaikan soal-soal } \\
\text { latihan secara mandiri atau kelompok } \\
\text { dan mempresentasikannya di papan } \\
\text { tulis kemudian dikoreksi bersama- } \\
\text { sama, dan siswa berlatih dengan } \\
\text { jawaban yang berbeda (redaksi } \\
\text { berbeda) tapi sama-sama benarnya. }\end{array}$ & Al Kabah \\
\hline 7 & $\begin{array}{l}\text { Penutup; kesimpulan, } \\
\text { memberikan motivasi, } \\
\text { berdo'a. }\end{array}$ & $\begin{array}{l}\text { Kerja Keras, disiplin, tanggung jawab, } \\
\text { relegius. Dimana siswa diberikan } \\
\text { motivasi untuk selalu meningkatkan } \\
\text { belajar dengan cara mendisiplinkan } \\
\text { diri dan mengatur waktu, serta } \\
\text { menggunakannya dengan sebaik- } \\
\text { baiknya. }\end{array}$ \\
\hline
\end{tabular}

\section{G. Kesimpulan dan Saran}

Dari paparan data dan uraian pembahasan, dapat diambil kesimpulan sebagai berikut;

1. Dalam mendesain Rencana Pelaksanaan Pembelajaran bahasa Arab guru bahasa MTs Al Maarif 01 Singosari telah memasukkan unsur penanaman karakter dalam rencana proses belajar mengajar yang dirancangnya. Namun dari unsur pendidikan karakter yang telah dicanangkan oleh pemerintah tidak semuanya bisa ditanamkan pada proses belajar mengajar, namun hanya unsur-unsur karakter yang sesuai dengan tema yang diajarkan. Adapun unsur karakter yang ditanamkan meliputi; Relegius, Peduli Lingkungan, Disiplin Diri, Rasa Ingin Tahu, Komunikatif/Bersahabat, Toleransi, Gemar Membaca, Kerja Keras, Tanggung Jawab.

2. Sedangkan implementasi pendidikan karakter pembelajaran bahasa Arab di MTs Al Maarif 01 Singosari sebagaimana dalam bentuk tabel berikut;

\begin{tabular}{|c|c|c|c|}
\hline No & Aktivitas Mengajar & $\begin{array}{c}\text { Nilai Karakter yang di } \\
\text { Tanamkan }\end{array}$ & Keterangan \\
\hline \multicolumn{4}{|c|}{ ال الساعة } \\
\hline 1 & $\begin{array}{l}\text { Pembukaan; Mengucapkan } \\
\text { salam, merapikan bangku, dan }\end{array}$ & $\begin{array}{l}\text { Relegius, } \quad \text { peduli } \\
\text { lingkungan }\end{array}$ & $\begin{array}{l}\text { Tema" As } \\
\text { Saa'ah" }\end{array}$ \\
\hline
\end{tabular}




\begin{tabular}{|c|c|c|c|}
\hline & berdo’a bersama & & \\
\hline 2 & Mengucapkan kosakata baru & $\begin{array}{l}\text { Disiplin diri, } \\
\text { Ingin tahu }\end{array}$ & Al Istma' \\
\hline 3 & $\begin{array}{l}\text { Memberikan contoh percakapan } \\
\text { sederhana, dan praktek } \\
\text { percakapan }\end{array}$ & $\begin{array}{l}\text { Komunikatif/bersahabat } \\
\text {, Toleransi }\end{array}$ & Al Kalam \\
\hline 4 & $\begin{array}{l}\text { Menjelaskan tata bahasa yang } \\
\text { terkandung dalam tema }\end{array}$ & Rasa Ingin Tahu. & \\
\hline 5 & $\begin{array}{l}\text { Memberikan contoh bahan } \\
\text { bacaan dan menjelaskan isi } \\
\text { kandungannya, dan praktek } \\
\text { membaca }\end{array}$ & $\begin{array}{l}\text { Gemar } \quad \text { Membaca, } \\
\text { disiplin, kerja keras }\end{array}$ & Al Qiro'ah \\
\hline 6 & $\begin{array}{l}\text { Memberikan contoh cara } \\
\text { mengerjakan soal-soal dalam } \\
\text { bentuk tulis tentang tema yang } \\
\text { dipelajari }\end{array}$ & $\begin{array}{l}\text { Tanggung Jawab, } \\
\text { Demokratis }\end{array}$ & Al Kitabah \\
\hline 7 & $\begin{array}{l}\text { Penutup; kesimpulan, } \\
\text { memberikan motivasi, berdo'a. }\end{array}$ & $\begin{array}{l}\text { Kerja Keras, disiplin, } \\
\text { tanggung } \\
\text { relegius. }\end{array}$ & \\
\hline \multicolumn{4}{|c|}{ النشاطات في المدرسة } \\
\hline 1 & $\begin{array}{l}\text { Mengucapkan salam, } \\
\text { merapikan bangku, dan berdo'a } \\
\text { bersama }\end{array}$ & $\begin{array}{l}\text { Relegius, } \quad \text { peduli } \\
\text { lingkungan. }\end{array}$ & $\begin{array}{l}\text { Tema "An } \\
\text { Nasyathot Fil } \\
\text { Madrasah" }\end{array}$ \\
\hline 2 & Mengucapkan kosakata baru & $\begin{array}{l}\text { Disiplin, Rasa Ingin } \\
\text { tahu. }\end{array}$ & Al Istma' \\
\hline 3 & $\begin{array}{l}\text { Memberikan contoh percakapan } \\
\text { sederhana, dan praktek } \\
\text { percakapan }\end{array}$ & $\begin{array}{l}\text { Komunikatif/bersahabat } \\
\text {, Toleransi. }\end{array}$ & Al Kalam \\
\hline 4 & $\begin{array}{l}\text { Menjelaskan tata bahasa yang } \\
\text { terkandung dalam tema }\end{array}$ & Rasa Ingin Tahu. & \\
\hline 5 & $\begin{array}{l}\text { Memberikan contoh bahan } \\
\text { bacaan dan menjelaskan isi } \\
\text { kandungannya, dan praktek } \\
\text { membaca }\end{array}$ & $\begin{array}{l}\text { Gemar } \quad \text { Membaca, } \\
\text { disiplin, kerja keras. }\end{array}$ & Al Qiro'ah \\
\hline 6 & $\begin{array}{l}\text { Memberikan contoh cara } \\
\text { mengerjakan soal-soal dalam } \\
\text { bentuk tulis tentang tema yang }\end{array}$ & $\begin{array}{l}\text { Tanggung Jawab, } \\
\text { Demokratis, } \\
\text { menghargai prestasi. }\end{array}$ & Al Kitabah \\
\hline
\end{tabular}




\begin{tabular}{|l|l|l|l|}
\hline 7 & dipelajari & $\begin{array}{l}\text { kesimpulan, } \\
\text { memutup; }\end{array}$ & $\begin{array}{l}\text { Kerja Keras, disiplin, } \\
\text { tanggung jawab, } \\
\text { relegius. }\end{array}$ \\
\hline
\end{tabular}

\section{SARAN}

1. Adanya aplikasi pendidikan karakter pada bidang studi bahasa Arab di Madrasah Tsanawiyah al Ma'arif 01, dan bidang studi- bidang studi yang lainnya sangat penting untuk dipertahankan dan ditingkatkan.

2. Peningkatan itu dapat dilakukan dalam hal dukungan lingkungan misalnya dengan penciptaan bi'ah 'arobiyah misalnya dengan menciptakan zona khusus bahasa Arab untuk meningkatkan keterampilan berbahasa siswa dalam rangka lebih mensukseskan karakter komunikatif/ bersahabat, dan toleransi pada semua lapisan masyarakat sekolah, baik kepala sekolah, semua guru, staf TU, dan masyarakat sekolah lainnya. Hal lain yang bisa dilakukan adalah dengan menyediakan majalah dinding berbahasa Arab karena hal ini amat penting untuk menciptakan karakter gemar membaca, disiplin dan kerja keras.

3. Upaya di atas dapat terjamin keberlangsungannya atau sustainabilitasnya jika ada lembaga yang bertanggungjawab dalam pelaksanannya, misalnya bagian kesiswaan atau yang lainnya. 


\section{DAFTAR PUSTAKA}

Dick \& Carey. 2001. The Systemic Dessign of Instruction $4^{\text {th" }}$ Ney York: Universitas of South Florida.

UU No 20 Tahun 2003 Tentang Sistem Pendidikan Nasional.

Pengembangan Pendidikan Budaya dan Karakter Bangsa, Pedoman Sekolah. Kementerian Pendidikan Nasional. Badan Penelitian dan Pengembangan Pusat Kurikulum Jakarta, 2010

Kagan, Spencer. Addressing the Life Skill Crisis. Kagan Online Magazine,Summer. http://www.KaganOnline. Com/ Magazine.

The Life Skill Curriculum, www philiproy. http://www.dehonrealty. com/oed/the life skill curriculum htm

Harjanto, 2008. Perencanaan Pengajaran. Jakarta : Rineka Cipta

Salim, Peter \& Salim,Yenny. 1991. Kamus Bahasa Indonesia Kontemporer. Jakarta: Modern English Press.

Damanik, Asan.2009. Pendidikan Sebagai Pembentuk Watak Bangsa. Sebuah Refleksi Konseptual Kritis dari Sudut Pandang Fisika.

Budiningsih, Asri. 2004. Pembelajaran Moral Berpijak Pada Karakter Siswa dan Budayanya. Jakarta: PT Asdi Mahasatya.

Mu'in, Fathul. 2011. Pendidikan Karakter Konstruksi Teoritik dan Praktik. Jogjakarta: Ar-Ruz Media.

Azzet, Akhmad Muhaimin. 2011. Urgensi Pendidikan Karakterdi Indonesia. Jogjakarta: Ar-Ruz Media.

Moleong, 1990. Metode Penelitian Kualitatif. Bandung: PT Remaja Rosdakarya.

Kasiram, Moh. 2010. Metodologi Penelitian Kualitatif -Kuantitatif. Malang: UINMaliki Press.

Arikunto, Suharsimi. 2006. Prosedur Penelitian Suatu Pendekatan Praktik. Jakarta: PT Rineka Cipta.

Ruyadi, Yadi. 2010. Proceedings of The 4th International Conference on Teacher Education; Join Conference UPI \& UPSI Bandung, Indonesia, 8-10 November 2010

Briggs, Leslie, J. 1979. Instructional Design : Prinsiples and Aplication. Educational Technology Publicatios : Englewood Cliffs, N.J. 